\title{
Is the formalization of collective tenure rights in the Peruvian Amazon supporting sustainable Indigenous livelihoods?
}

\section{Findings from comparative research in San Martín and Ucayali regions}

Miguel Guerra, Juan Pablo Sarmiento Barletti and Blanca Begert

\section{Key findings}

- $\quad$ The titling of Comunidades Nativas (Native Communities) alone is not enough to ensure Indigenous Peoples' access to sustainable livelihoods in the Peruvian Amazon.

- $\quad$ Lack of income options, combined with restrictive legal frameworks for resource use under the Comunidad model, led to unsustainable land and resource use.

- In seeking to access cash incomes, Comunidades often entered into exploitative relationships with smallholder migrant farmers and timber companies.

- Regulations for resource use and the Comunidad's governance framework do not reflect local livelihoods and leadership practices; interviewees highlighted that this created challenges related to livelihoods, conflicts, participation and representation in communal governance.

- A transition from a punitive to an enabling role for government agencies - including investing to develop both the institutional and technical capacities of Comunidades - is essential to support more sustainable livelihoods.

\section{Introduction}

Forested areas under community management regimes are more effective at maintaining forest cover than other land management arrangements, including some protected areas (RRI 2017; Schleicher et al. 2017; Garnett et al. 2018). Studies show that secure collective land rights allow communities to better protect their forests, emphasizing the compatibility of Indigenous Peoples' environmental management practices with carbon sequestration (Yeh and Bryan 2015; Blackman et al. 2017; RRI 2018). Indigenous grassroots organizations advocate for formal recognition of their rights to land and resources as the most important mechanism by which to secure their livelihoods (Seymour et al. 2014).

However, even after communities have received legal titles to their lands, tenure reforms throughout Latin America continue to restrict the livelihoods options that Indigenous Peoples are able to pursue (see Monterroso et al. 2019). Laws governing access to land and forests often do not consider the priorities, institutions and resource use practices of Indigenous and local communities (Stocks 2005; Larson et al. 2015; Sarmiento Barletti 2017) and instead limit their ability to access forest resources and develop sustainable livelihoods from forests. As a result, informal practices remain widespread, and local people are often unjustly penalized (Duffy 2010; Pacheco et al. 2012; Maryudi and Myers 2018).

In this infobrief we summarize findings from a recently published article (Sarmiento Barletti et al. 2021) to explore the extent to which the titling of Comunidades Nativas (Native Communities) - the collective lands of Indigenous Peoples in the Peruvian Amazon - is supporting Indigenous Peoples' abilities to effectively conserve forests and secure sustainable livelihoods. We analyse how the inhabitants of six Comunidades, in the Peruvian regions of San Martín and Ucayali, perceive their livelihood options and manage their resources and territories. We synthesize challenges faced by our informants into three key areas: (i) livelihoods, (ii) conflicts, and (iii) participation and representation in communal governance.

This infobrief starts by briefly contextualizing how the current Comunidad Nativa legal framework was developed in Peru. We then present our research methodology and study sites, before summarizing our results and synthesizing them into broader lessons. The conclusion then summarizes our findings. 


\section{The Comunidad Nativa}

Three key transition periods mark the history of legal recognition of Indigenous territories in Peru (Monterroso et al. 2017); these are helpful to understand the current legal framework for Comunidades.

- The first period (1969-1979) was marked by the emergence of Law No. 20653 (1974), the Law of Native Communities and Promotion of Agriculture in the Lower and Upper Rainforests. This law initiated recognition of Comunidades Nativas, granting their inhabitants inalienable collective rights over areas that included forests. These rights could not lapse nor could their lands be seized. However, the law was modified in 1978 to introduce a distinction between agricultural and forested land within a Comunidad's territory. This placed forests under government control.

- The second period (1980-2009) saw a move away from the formalization of collective rights to focus on individual property rights. Laws were passed to make it easier for community members to vote to divide their collective land into separate parcels. The titling process more generally was paused and policies allowed for 'unused' land to be appropriated by the state. The emergence of multiple government institutions with responsibilities related to titling and to the resources in Comunidades Nativas made it harder for Indigenous Peoples to comply with legal procedures (including those related to resource use) and to engage effectively with government offices.

- The third period (2009 onwards) returned to an emphasis on collective tenure rights and has been marked by the passing of the Law of Prior Consultation. International agreements related to Peru's climate change goals led to multiple ongoing large-scale titling efforts funded by multilateral institutions.
Despite progress in titling, Peru continues to pursue an extractive-led development agenda. By 2010, almost $50 \%$ of Peru's Amazon fell within one of 52 hydrocarbon concessions, compared with only $7.1 \%$ in 2003; 46 of those concessions overlapped Comunidades (Finer and OrtaMartínez 2010). Yet between 2006 and 2011, Indigenous territories in the Peruvian Amazon reduced deforestation twice as much as protected areas with similar ecological conditions and accessibility (FAO and FILAC 2021). Although more than 1,300 Comunidades have been titled since 1974, another 600 others (spanning around 5.5 million ha) are still pending (Notess et al. 2018). Progress has been underwhelming, primarily because titling remains legally, politically and technically cumbersome (Notess et al. 2020).

Against this background, we ask: is the Comunidad Nativa supporting Indigenous Peoples' access to sustainable livelihoods? To explore this, we present research findings from research with six Comunidades.

\section{Methods and case studies}

Research was carried out between June and October 2019 in three Awajún Comunidades in San Martín and three Asháninka Comunidades in Ucayali (see Table 1). Across all sites, we implemented qualitative methods including semistructured interviews, document analysis and participant observation (see Sarmiento Barletti et al. 2021 for the full methods). Research sought to understand how people in Comunidades perceive their livelihood options and manage their territories. Although socioenvironmental pressures and political priorities differ in San Martín and Ucayali - Peru's foremost coffee production and timber extraction areas, respectively - Indigenous Peoples face similar pressures due to the land and resource regimes governing Comunidades, local and national development agendas, and the interests of other actors in their territories.

Table 1. Community profiles

\begin{tabular}{|c|c|c|c|c|c|c|}
\hline \multirow{2}{*}{$\begin{array}{l}\text { Region } \\
\text { Comunidad }\end{array}$} & \multicolumn{3}{|c|}{ San Martín (Awajún) } & \multicolumn{3}{|c|}{ Ucayali (Asháninka) } \\
\hline & Alto Mayo & Alto Naranjillo & Cachiyacu & Inkare & Nueva Esperanza & Tzinquiato \\
\hline \multirow{2}{*}{$\begin{array}{l}\text { Area and } \\
\text { population }\end{array}$} & 11,106 ha & 3,625 ha & 29,473 ha & 3,783 ha & 4,752 ha & 6,717 ha \\
\hline & 622 people & 128 people & 105 people & 71 people & 470 people & 200 people \\
\hline $\begin{array}{l}\text { Year } \\
\text { established/ } \\
\text { titled }\end{array}$ & 1950s/1999 & 1974/1999 & $\sim 1990 / 1996$ & 1990/1991 & 1987/1992 & 1989/1994 \\
\hline Main conflicts & $\begin{array}{l}\text { Land renting } \\
\text { to migrants, } \\
\text { overlaps with a } \\
\text { protected area }\end{array}$ & $\begin{array}{l}\text { Land renting } \\
\text { to migrants }\end{array}$ & $\begin{array}{l}\text { Land invasion, } \\
\text { overlaps with } \\
\text { a mining } \\
\text { concession and } \\
\text { a conservation } \\
\text { area }\end{array}$ & $\begin{array}{l}\text { Debt with a } \\
\text { timber company }\end{array}$ & $\begin{array}{l}\text { Debt with a timber } \\
\text { company }\end{array}$ & $\begin{array}{l}\text { Land invasion } \\
\text { issues with } \\
\text { Andean } \\
\text { migrants }\end{array}$ \\
\hline $\begin{array}{l}\text { Current } \\
\text { engagement } \\
\text { with projects }\end{array}$ & $\begin{array}{l}\text { Programa } \\
\text { Bosques / } \\
\text { Conservation } \\
\text { International }\end{array}$ & $\begin{array}{l}\text { Small } \\
\text { reforestation } \\
\text { programme } \\
\text { with the } \\
\text { regional } \\
\text { government }\end{array}$ & None & $\begin{array}{l}\text { Programa } \\
\text { Bosques }\end{array}$ & None & $\begin{array}{l}\text { Programa } \\
\text { Bosques }\end{array}$ \\
\hline
\end{tabular}


Awajún Comunidades were selected in coordination with the Regional Indigenous Awajún Federation of the Alto Mayo (FERIAAM). In total, 16 in-depth semi-structured interviews were conducted in Awajún communities, as well as 7 focus groups. Asháninka Comunidades were selected in coordination with the Asháninka Federation for the Bajo Urubamba (FABU). In these areas, 47 in-depth interviews with community members were conducted, in addition to 6 focus groups.

Awajún and Asháninka Peoples are the two most numerous Indigenous Amazonian societies in Peru, with 65,828 and 112,492 people respectively (INEI 2017). Traditional Awajún and Asháninka communities formed small kin-based groups of around 30-50 inhabitants. Groups lived dispersed, around one-day walking distance from each other, in territories much larger and less populated than current Comunidades (Killick 2007; Greene 2009). Studies note that the distance between households would allow family groups to manage the natural resources around them - mostly fish and game, as agriculture was small-scale and subsistence oriented without having to coordinate use with other family groups from day to day. Family groups still lived close enough to visit each other for activities including rituals and communal fishing trips (Gow 1991; Killick 2007).

Today, many different families live within the boundaries of one Comunidad, commonly living side by side in villages of varying sizes. The Law of Native Communities imposed an Andean community model, based around agriculture, on Amazonian peoples who had previously lived in more mobile and dispersed patterns (Greene 2009). The social organization of Comunidades now resembles a settled and nuclear community model, where parts of Comunidades are divided into parcels for individual families to farm and profit from, while other portions are managed collectively, as per Comunidad regulations. The most important resource that is managed collectively is standing forests; farms are owned and managed by individuals, with little rules about where they can be located.

In the early 1980s, Asháninka farm plots were recorded to include more than two dozen different foodstuffs, which supplemented diets of game and fish; conversely, farm plots in the 2000s had less than a quarter of those plants (Hvalkof and Veber 2005). Cacao and coffee - the most important cash crops in San Martín and Ucayali - were introduced in recent decades, although much later in Ucayali, where the local economy has historically been based on logging. In both regions, there is recent support from government and NGO actors for cacao and coffee planting to discourage deforestation from logging and farm plot expansion.

As with most Indigenous Amazonian societies, traditional Asháninka and Awajún social organization had virtually no coercive leadership roles (outside war and ritual practice) in a sociopolitical context where land was freely available and thus people were able to move away and start new settlements when they disagreed with the decisions made by a leader (Greene 2009) or to avoid conflicts (Weiss 1975). The Law of Native Communities determined that a communal assembly, composed of all adult members in a Comunidad, should elect a president to serve as its legal representative. In the early years of Comunidades, young men that could read and write in Spanish were selected as presidents, but they had no real impact on communitywide decision making (Brown 1993; Renard-Cassevitz 1993). Arguably, this could be because Comunidades at the time had few formal external engagements.

Over time, the increase in economic negotiations with outsiders over resources in the Comunidad (e.g., timber, land) granted presidents certain advantages over their neighbours, as they had the legal power to make and profit from these deals while, at least officially, representing the Comunidad (Greene 2009; Sarmiento Barletti 2017). Today, the renting of Comunidad land to outsiders, or the signing of logging agreements with companies, is normally approved by its president or by the communal assembly, but all legal agreements must be signed by the president.

\section{Results}

Research participants' perspectives can be grouped into the three main challenges they faced despite having titled lands (all Comunidades in our study were titled in the 1990s). First, participants highlighted that their income from selling cash crops in local markets was insufficient, so they had to supplement it with informal land and resource use activities that exposed them to exploitative relationships. Second, they reported conflicts with Indigenous and non-Indigenous actors over their Comunidades' land and resources. Third, they noted communal governance challenges - specifically, gendered decision-making disparities within Comunidades and the abuse of presidential authority.

\section{Livelihoods}

Awajún informants expressed difficulties earning a living from agriculture, as well as affording healthcare, school supplies and food. Primary income came from selling coffee, complemented by renting land to Andean migrants. Starting in the 1990s, government loans and policies to integrate Awajún Comunidades into the national economy through agriculture, coupled with scant technical capacity support, an increased need for money, and shrinking forest resources, led Awajún Comunidades to rent land to migrant farmers (Greene 2009). By the late 1990s leasing was widespread, and during the early 2000s Awajún Comunidades in San Martín experienced some of the highest forest loss in all of Peru. Focus groups attributed forest loss primarily to land rentals and migrant neighbours. Informants had little desire to expand their agricultural plots, given their limited capacity to work larger areas. Timber was never discussed as a primary motivation for land clearing. In San Martín, most Comunidades had divided land for agriculture and renting by parcelling out parts of their territory to individual families. Heads of households could decide to rent land and receive the income, but leases were approved and signed by the Comunidad's president. 
At the time of research, income in Asháninka Comunidades was primarily obtained from cacao sales, supplemented with informal timber extraction to cover household needs. Respondents described the formal logging process as complicated and expensive; following the regulations requires accounting and technical capacities that only timber companies have. This has forced Comunidades either to rely on unfair contracts with timber companies that had the know-how to get legal permits, or to opt for informal logging. While informal extraction by individuals is aimed at meeting immediate economic needs, logging can also be carried out with timber companies at the Comunidad level, and income is later divided among the families. Deals with loggers are common, as they offer loans or products to Comunidades against future timber; all three Asháninka Comunidades in this study were in debt to timber companies. Comunidades enrolled in Programa Bosques - Peru's National Programme for Forest Conservation explained that despite capacity development sessions, the project's benefits never solved family or personal needs because the funds can only be used for communal conservation and livelihood development projects. Awajún informants also expressed a desire for more cash support, to complement the non-governmental conservation programmes in their territories that fund sustainable livelihood projects, trainings, and materials.

\section{Conflicts}

Land conflicts with outsiders were reported across all sites. All 12 Awajún Comunidades represented by FERIAAM have conflicts with migrant farmers (IPE 2018) and all 14 Comunidades represented by FABU had resource extraction and agricultural expansion conflicts with outsiders. Awajún Comunidades intend to phase out rentals because they have led to economic dependence on migrants, deforestation, and land dispossession that occurs when migrants refuse to leave once leases expire. Conflicts with renters, as well as with migrants who invade Awajún territories (without paying rent), have resulted in violent clashes. Formal conflict resolution channels are costly, lengthy and tend to favour migrants; in some cases, the government encouraged rentals as a solution to land invasions, which only prolonged the conflict (Kowler et al. 2016). In Asháninka Comunidades, although outsiders cleared areas for cultivation within their territories, this was tolerated so long as these areas were not used for cash crops; logging by outsiders was also not tolerated. Hydrocarbon concessions were also reported as a threat, as all Asháninka Comunidades were overlapped by one.

\section{Representation and participation}

Research revealed two types of power asymmetries in Comunidades: gender-based inequalities and concerns related to the president's power. The Indigenous organizations in both study areas said that they would like at least $50 \%$ of their Comunidad leadership roles to be occupied by women, but they had no concrete plan to achieve this. Although Asháninka women occupied leadership positions in some Comunidades, respondents noted that fulfilling those roles on top of household work is harder for women than for men. In focus groups, Awajún women said that their opinions do not reach authorities; Asháninka women were reluctant to express their opinions in assemblies, especially in meetings concerning timber deals. Domestic violence towards women was also mentioned across all study sites.

Awajún informants noted they were not always informed about presidents' dealings regarding the forest or agreements with NGOs. Presidents' shifting approaches to land invasions had also driven conflict, such as when prior leaders had allowed settlers to remain on the land, leading to increased tensions when new leadership wanted them to leave (see also Kowler et al. 2016). Most Asháninka respondents disapproved of logging in their Comunidades but accepted it because their presidents had signed contracts with companies. In the area, companies target Comunidad presidents to pressure them into signing contracts. Assuming leadership positions was perceived as a burden in Asháninka Comunidades because presidents must invest money and time without compensation, which tended to lead to poorly engaged leaders eager to drop responsibility once their mandates were over.

\section{Discussion}

Findings align with discussions of how regulatory frameworks limit the scope of rights granted during title formalization processes (Stocks 2005; RRI 2012; Larson et al. 2015). Our six case studies show how lack of income options and restrictive legal frameworks led to unsustainable and inequitable land and resource use, including renting land to migrants and extracting timber informally. In Asháninka communities there was strong government support for cacao cultivation, but no support was provided for market engagement or for alternative crops.

We found that the Comunidad Nativa framework presents challenges, as does a lack of government support for Indigenous Peoples to thrive within that framework. Research led to four wider lessons.

1. First, there is a contradiction between the state's roles as the driver of an extractive agenda and as the guarantor of Indigenous rights. Enabling Indigenous communities to access their rights requires the state to play an active and supportive role, but evidence shows that the Peruvian state has other priorities. The Comunidad model provides only a partial devolution of land and resource rights; informants were only able to freely use land that had been classified as agricultural, and found that the challenging process to extract timber legally was a barrier to improved livelihoods.

2. Second, official channels for both conflict resolution and formal logging are cumbersome and restrictive, favouring informality. Instead of supporting Comunidades' land rights and resolving disputes, local governments encouraged Awajún people to rent out land, yield to economic agreements, or grant usufruct rights to migrants. Loggers are, 
on many occasions, the only actors that provide immediate income to Asháninka people to ensure health, education and other basic household needs; a significant absence of cash and social services forces Comunidades to accept loans at excessive costs that must be paid in timber.

3. Third, laws and external initiatives treat Comunidades as cohesive units of production, where all their members have similar livelihood goals, often emphasizing non-monetary, collective benefits. However, initiatives must consider the diversity of strategies that families within the same Comunidad opt for to fulfil their livelihood goals. Our interviewees prioritised their families' incomes; although Comunidades need communal benefits, insufficient support for individual livelihoods may foster informal resource use.

4. Fourth, the Comunidad governance model may clash with some Indigenous forms of governance, and with the ways Comunidades view their presidents. The president's signature on a contract or loan establishes the Comunidad's legal responsibility, and they are not protected from the negative consequences of these deals; decisions made by presidents could be catalysts for debt and conflict (see also Larson et al. 2015). Although communal assemblies are meant to give one vote per community member, women were not adequately heard nor represented in community decision-making processes.

\section{Conclusion}

Findings show that the Comunidad model and the laws and interests around it are not supportive of sustainable livelihoods for their inhabitants. Across all sites, challenges in earning sufficient income through formal mechanisms were reported, resulting in informal income-generating activities, placing community members in exploitative relationships and at risk of penalties. Logging regulations in Ucayali and commercial agriculture systems in San Martín require capacities and resources that Indigenous Peoples do not have, resulting in one-sided deals with timber companies or Andean migrants. The system also supports leadership without clear lines of accountability, and there are gendered inequalities in participation and decision making. Trying to resolve conflicts over Indigenous titled lands following official routes led to further challenges or to others benefiting.

Findings call for a transition from a punitive to an enabling role for government agencies. There is an urgent need to establish forestry and tenure regulations that reflect the local livelihoods, representation practices and needs of Comunidades. At the very least, investment in targeted capacity, institutional, and technical development in Comunidades must be fostered. This would allow Indigenous Peoples to navigate the legal aspects of resource use and land conflicts, strengthen their internal decision-making mechanisms (see Stocks 2005), and enable their organizations to participate more equitably in decisions that affect their territories and futures, including having more equitable and informed involvement in markets for their products.

\section{Acknowledgements}

We would like to thank the six communities where research was carried out, as well as FABU and FERIAAM, their representative organizations. We also thank Evan Killick, Giancarlo Rolando and Anne Larson for their comments on this infobrief, and the anonymous reviewers at the International Journal for the Commons for their help in improving our original manuscript. This work was funded by the CGIAR Research Program on Policies, Institutions and Markets (PIM) led by the International Food Policy Research Institute (IFPRI), and the Norwegian Agency for Development Cooperation.

\section{References}

Blackman A, Corral L, Santos Lima E and Asner G. 2017. Titling Indigenous communities protects forests in the Peruvian Amazon. PNAS 114(16).

Brown M. 1993. Facing the state, facing the world: Amazonia's native leaders and the new politics of identity. L'Homme 126-128:307-326.

Duffy R. 2010. Nature crime: How we are getting conservation wrong. New Haven: Yale University Press.

FAO (Food and Agriculture Organization of the United Nations) and FILAC (Fund for the Development of the Indigenous Peoples of Latin America and the Caribbean). 2021. Forest Governance by Indigenous and Tribal People. Santiago: FAO.

Finer M and Orta-Martínez M. 2010. A second

hydrocarbon boom threatens the Peruvian Amazon. Environmental Research Letters 5.

Garnett ST, Burgess ND, Fa JE, Fernandez-Llamazares A, Molnar Z, Robinson CJ, Watson JEM, Zander KK, Austin B, Brondizio ES, et al. 2018. A spatial overview of the global importance of Indigenous lands for conservation. Nature Sustainability 1(7): 369-374.

Greene S. 2009. Customizing indigeneity. Stanford: Stanford University Press.

Gow P. 1991. Of mixed blood: Kinship and history in the Peruvian Amazon. Oxford: Oxford University Press.

Hvalkof S and Veber H. 2005. Los asheninka del Gran Pajonal. In Santos-Granero F and Barclay F, eds. Guia etnografica de la alta amazonia. Lima: IFEA, pp. 75-280.

INEI (Instituto Nacional de Estadísticas e Informática). 2017. Censo Nacional. Peru: INEI.

IPE (Instituto Paz y Esperanza). 2018. Protierras Comunales. Peru: GIZ.

Killick E. 2007. Creating community: Land titling, education and settlement formation among the Asheninka of Peruvian Amazonia. Journal of Latin American and Caribbean Anthropology 13:22-47.

Kowler L, Ravikumar A, Larson A, Rodriguez-Ward D and Burga C. 2016. Analyzing multilevel governance in Peru. CIFOR Working Paper 203. Bogor, Indonesia: CIFOR.

Larson AM, Cronkleton P and Puhlin JM. 2015. Formalizing Indigenous commons: The role of 'authority' in the formation of territories in Nicaragua, Bolivia and the Philippines. World Development 70:228-238. 
Maryudi A and Myers R. 2018. Renting legality: How FLEGT is reinforcing power relations in Indonesian furniture production networks. Geoforum 97:46-53.

Monterroso I, Cronkleton P and Larson AM. 2019. Commons, indigenous rights, and governance. In Hudson $\mathrm{B}_{\text {, }}$ Rosenbloom J and Cole D, eds. Routledge Handbook of the Study of the Commons. New York: Routledge, pp. 376-391.

Monterroso I, Cronkleton P, Pinedo D and Larson AM. 2017. Reclaiming collective rights: Land and forest tenure reforms in Peru. CIFOR Working Paper 224. Bogor, Indonesia: CIFOR.

Notess L, Veit PG, Monterroso I, Andiko, Sulle E, Larson AM, Gindroz A-S, Quaedvlieg J and Williams A. 2020 Community land formalization and company land acquisition procedures: A review of 33 procedures in 15 countries. Land Use Policy 110.

Notess L, Veit PG, Monterroso I, Andiko, Sulle E, Larson AM, Gindroz A-S, Quaedvlieg J and Williams A. 2018. The scramble for land rights. Washington DC: World Resources Institute.

Pacheco P, Barry D, Larson AM and Cronkleton P. 2012. The Recognition of Forest Rights in Latin America: Progress and Shortcomings of Forest Tenure Reforms. Society \& Natural Resources 25:556-571

Renard-Cassevitz F-M. 1993. Guerriers du sel, sauniers de la paix. L'Homme 126-128:25-43.

RRI (Rights and Resources Initiative). 2018. A global baseline of carbon storage in collective lands. Washington DC: RRI.

RRI. 2017. Securing community land rights. Washington DC: RRI.
RRI. 2012. What rights? A comparative analysis of developing countries' national legislation on Community and Indigenous Peoples' forest tenure rights. Washington DC: RRI.

Sarmiento Barletti JP. 2017. The rise of the egalityrant in postwar Peruvian Amazonia. In Virtanen $\mathrm{P}$ and Veber $\mathrm{H}$, eds. Indigenous perceptions and forms of leadership in Amazonia. Boulder: UCP, pp. 45-64.

Sarmiento Barletti JP, Begert B and Guerra Loza MA. 2021. Is the formalization of collective tenure rights supporting sustainable Indigenous livelihoods? Insights from Comunidades Nativas in the Peruvian Amazon. International Journal of the Commons 15(1):381394. https://doi.org/10.5334/ijc.1126

Schleicher J, Peres C, Amano T, Llactayo W and LeaderWilliams N. 2017. Conservation performance of different conservation governance regimes in the Peruvian Amazon. Scientific Reports 7:1-10.

Seymour F, La Vina T and Hite K. 2014. Evidence linking community level tenure and forest condition. San Francisco: CLUA.

Stocks A. 2005. Too much for too few: Problems of Indigenous land rights in Latin America. Annual Review of Anthropology 34:85-104.

Weiss G. 1975. Campa cosmology. New York: AMNH.

Yeh E and Bryan J. 2015. Indigeneity. In Bryant R, ed. The International Handbook of Political Ecology. London: Elgar.

\begin{tabular}{|l|l|l|}
\hline $\begin{array}{l}\text { RESEARCH } \\
\text { PROGRAM ON } \\
\text { Policies, } \\
\text { Institutions, } \\
\text { and Markets } \\
\text { Led by IFPRI }\end{array}$ & $\begin{array}{l}\text { The CGIAR Research Program on Policies, Institutions, and Markets (PIM) leads action-oriented research } \\
\text { to equip decisionmakers with the evidence required to develop food and agricultural policies that better } \\
\text { serve the interests of poor producers and consumers, both men and women. PIM combines the resources } \\
\text { of CGIAR centers and numerous international, regional, and national partners. The program is led by the } \\
\text { International Food Policy Research Institute (IFPRI). www.pim.cgiar.org }\end{array}$ \\
CGIAR
\end{tabular}

\begin{tabular}{|l|l|l|l} 
This research was carried out by CIFOR as part of the CGIAR Research Program on Forests, Trees and \\
Agroforestry (FTA). FTA is the world's largest research for development program to enhance the role \\
of forests, trees and agroforestry in sustainable development and food security and to address climate \\
change. CIFOR leads FTA in partnership with Bioversity International, CATIE, CIRAD, INBAR, ICRAF and TBI. \\
FTA's work is supported by the CGIAR Trust Fund: cgiar.org/funders/
\end{tabular}

